УДК 378:37.091.12:36-051]:352(1-037)

DOI:

Лілія Шульгіна, аспірант кафедри педагогіки та менеджменту освіти Тернопільського національного педагогічного університету імені Володимира Гнатюка

\title{
ТЕОРЕТИКО-МЕТОДОЛОГІЧНІ ЗАСАДИ ЗАБЕЗПЕЧЕННЯ ЯКОСТІ ПІДГОТОВКИ СОЦІАЛЬНОГО ПРАЦІВНИКА ДО СТВОРЕННЯ ДОСТУПНОГО СЕРЕДОВИЩА В СИСТЕМІ ОБ'ЄДНАНОЇ ТЕРИТОРІАЛЬНОЇ ГРОМАДИ
}

У статті визначено, щзо теоретико-методологічними засадами підготовки майбутніх соціальних працівників є історико-ретроспективні віхи розвитку та фундаменталізації соціальної роботи. Соціальна робота розглядається як практична професійна діяльність з надання допомоги та підтримки людям; як навчальна дисципліна для підготовки фахівців із соціальної допомоги та підтримки населення; як галузь наукових знань. До методологічних підходів віднесено: особистісно-орієнтований, інтегративний, компетентісний. Проаналізовано сучасні нормативно-правові документи, які регламентують професійну діяльність сочіальних працівників.

Ключові слова: соціальна робота; соціальний працівник; якість підготовки; спеціаліст соціальної підготовки; професійність социіального працівника.

$\operatorname{Iim} .17$.

Liliya Shulhina, Postgraduate Student of the Pedagogy and Management of Education Department, Ternopil Volodymyr Hnatyuk National Pedagogical University

\section{THEORETICALAND METHODOLOGICAL BACKGROUND OF ENSURING QUALITY SOCIAL WORKER TRAINING FOR CREATING AN ACCESSIBLE ENVIRONMENT IN THE AMALGAMATED TERRITORIAL COMMUNITY SYSTEM}

In the pedagogical science of higher education, research material has been accumulated on various aspects of improving the process of training of social work specialists in general, which allows us to raise the issue of clarifying the construction of pedagogical support for the process of preparing them for creating an accessible environment in the system of a united territorial community. The most important task facing teachers is to find effective conditions for preparing a future specialist in social work for practical activity in certain conditions. The analysis of scientific literature showed the lack of targeted research by researchers in the direction of developing theoretical and methodological foundations for training future social workers to create an accessible environment in the system of a united territorial community. The article determines that the theoretical and methodological principles of training future social workers include historical and retrospective milestones in the development and fundamentalization of social work. The concept of a social worker has been defined - this is a professionally trained specialist who has the necessary qualifications in the field of social work and provides social services to state and non-state organizations. Social work is seen as a practical professional activity to help and support people; as an academic discipline for training specialists in social assistance and support of the population; as a branch of scientific knowledge. Methodological approaches include: personality-oriented, integrative, and competence-based. The author analyzed the modern regulatory documents governing the professional activities of social workers in the system of the united territorial community. The fundamental research of the problems of professional training of social work specialists is revealed.

Keywords: social work; a social worker; quality of training; a social training specialist; professionalism of a social worker.

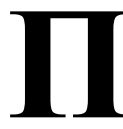

остановка проблеми. Проблема якості освіти завжди перебувала в полі зору як педагогічної теорії, так i практики освіти. Сьогодні якість освіти розглядається як найважливіший фактор стабільного розвитку країни. У педагогічній науці вищої школи накопичено дослідницький матеріал 3 різних аспектів вдосконалення процесу підготовки фахівців соціальної роботи в цілому, що дозволяє в даний час поставити питання про уточнення побудови педагогічного забезпечення процесу їх підготовки до створення доступного середовища в системі об’єднаної територіальної громади.

Найважливіше завдання, що стоїть перед педагогами - знайти ефективні умови для підготовки майбутнього фахівця соціальної роботи до практичної діяльності в окреслених умовах. Основне завдання професійної освіти - підготовка кваліфікованого працівника відповідного рівня і профілю, конкурентоздатного на ринку праці, компетентного, відповідального, що вільно володіє своєю професією і орієнтованого в суміжних областях діяльності, здатного до ефективної 


\section{ТЕОРЕТИКО-МЕТОДОЛОГІЧНІ ЗАСАДИЗАБЕЗПЕЧЕННЯ ЯКОСТІ ПДГОТОВКИСОЦАЛЬНОГО ПРАЦІВНИКА ДОСТВОРЕННЯ ДОСТУПНОГОСЕРЕДОВИЩА В СИСТЕМІ ОБ'ЄДНАНОЇ ТЕРИТОРІАЛЬНОӤ ГРОМАДИ}

роботи за фахом на рівні світових стандартів, готового до постійного професійного зростання, соціальної і професійної мобільності; задоволення потреб особистості в отриманні відповідної освіти.

Аналіз основних досліджень і публікацій. Як резюмує Т. Семигіна $[11,93]$, проблему дослідження сутності, змісту й особливостей професійної підготовки майбутніх соціальних працівників у вітчизняній системі освіти, а також теоретичні і практичні аспекти соціальної роботи розглянуто у працях О. Беспалько, В. Беха, А. Горілого, А. Капської,О. Карпенко, М. Лукашевича, I. Мельничук, І. Миговича, В. Поліщук, В. Полтавця, Т. Семигіної, Л. Тюпті, Ю. Швалба та ін. Окреслену проблему розкрито й у роботах зарубіжних дослідників (Л. Гуслякової), Ф. Сейбла, С. Тетерського, С. Холостової, Б. Шапіро, Н. Шмельової та ін) [2; 5; 6; 10; 12]. Питання, пов'язані з формуванням особистіснопрофесійних якостей фахівця із соціальної роботи, висвітлено у дослідженнях М. Васильєвої, Н. Клименюк, О. Патинок та ін.

Наукові пошуки сучасних дослідників спрямовано на всебічне вивчення професійної культури майбутніх соціальних працівників (Г. М'ясоїд, О. Повідайчик, О. Урсол та ін.); опрацювання психологічних механізмів професіоналізму (К. Уршуля ); професійного самовдосконалення (Н. Троценко); формування вмінь іншомовного спілкування (О. Канюк) та різних аспектів готовності: інтегративної (Л. Прудка); надання клієнтам соціальноекономічних послуг (А. Приходько); до профорієнтаційної роботи з безробітною молоддю (Л. Горбань); менеджменту в соціальній роботі (Є. Дєдов). Окремі аспекти підготовки майбутніх соціальних працівників до роботи з різними групами населення й надання різних видів послуг відображено у працях М. Дідик, Р. Козубовського, С. Сургової та ін. Аналіз наукової літератури засвідчив відсутність цілеспрямованих розвідок дослідників у напрямі розробки теоретикометодологічних засад підготовки майбутніх соціальних працівників до створення доступного середовища в системі об'єднаної територіальної громади. Однак знаходимо дослідження, що присвячене проблемі підготовки студентів цієї спеціальності до роботи в умовах об'єднаної територіальної громади.

Формування мети статті. Мета статті полягає у вивченні теоретико-методологічних засад підготовки майбутніх соціальних працівників до створення доступного середовища в системі об’єднаної територіальної громади.

Виклад основного матеріалу. Слід зазначити, що ефективність майбутньої професійної діяльності сучасного фахівця соціального працівника, залежить від рівня виявлення специфіки його особистісних та функціональних характеристик, остаточно - від його професійної компетентності, формування якої відбувається в процесі фахової підготовки у закладі вищої освіти. Окреслені пріоритети є основою компетнтніснісного підходу, який передбачає, з одного боку - особистий розвиток студента, а з іншого - вдосконалення професійної діяльності педагога [3; 4].

Модернізація освіти на основі реалізації компетентнісного підходу трансформує систему вітчизняної освіти відповідно до сучасних загальноєвропейських вимог [8; 9]. Використання нової парадигми покликано сприяти викоріненню традиційних орієнтацій освіти, актуалізувати іiі практичну складову та спрямувати активність студента від пасивного засвоєння знань до дослідницької, самостійної та самоосвітньої діяльності. Необхідність реалізації в навчальновиховному процесі компетентнісного підходу відображено в багатьох документах, зокрема Національній рамці кваліфікацій [7], де вказано, що професійна підготовка фахівців повинна поєднувати інтелектуальну та діяльнісну складову, розвивати нову інтерпретацію змісту освіти, що формується “від результату”, здійснюватися на основі європейських стандартів та принципів забезпечення якості освіти 3 урахуванням вимог ринку праці до компетентностей фахівців тощо.

Відтак професійну підготовку майбутніх соціальних працівників слід розглядати з позицій компетентнісного підходу, який переміщує акценти 3 процесу накопичення знань, вмінь та навичок у площину формування й розвитку в студентів здатності практично діяти і застосовувати набуті знання і досвід в професійних ситуаціях. Реалізація компетентнісного підходу вимагає нового проектування як результатів освіти, так і освітнього процесу та механізмів управління ним.

Сучасну підготовку майбутніх соціальних працівників науковці $[16,120 ; 17,24]$ визначають як процес, результатом якого є формування готовності до певної професійної діяльності; цілісний неперервний процес становлення особистості майбутнього виконавця соціальної роботи та формування фахівця нового типу, котрий має швидко й адекватно реагувати на зміни в суспільстві, компетентно вирішувати соціальнопедагогічні проблеми; систему організаційнометодичних заходів, які забезпечують формування готовності до професійної діяльності, 


\section{ТЕОРЕТИКО-МЕТОДОЛОГІЧНІ ЗАСАДИЗАБЕЗПЕЧЕННЯ ЯКОСТІПДГОТОВКИСОЦАЛЬНОГО ПРАЦІВНИКА ДО СТВОРЕННЯ ДОСТУПНОГОСЕРЕДОВИЩА В СИСТЕМІ ОБ'ЄДНАНОЇ ТЕРИТОРІАЛЬНОЇ ГРОМАДИ}

що охоплює професійну спрямованість, знання, уміння, навички.

Резюмування наукової літератури дало змогу виокремити теоретико-методологічне підгрунтя підготовки майбутніх соціальних працівників до створення доступного середовища в системі об'єднаної територіальної громади. Зважаючи на той факт, що професія “соціальний працівник” $\epsilon$ нової для українських реалій, доцільно опиратися на історичні віхи фундаменталізації соціальної роботи як практичної професійної діяльності 3 надання допомоги та підтримки людям; як навчальної дисципліни для підготовки фахівців із соціальної допомоги та підтримки населення; як галузі наукових знань.

Становлення і розвиток системи професійної підготовки фахівців соціальної сфери припадає на останнє десятиліття XX ст. Це період кризи політичної системи, складних негативних змін в соціально-економічної життя більшості українських сімей. Зважаючи на це, підготовка працівників соціальних служб, здатних надати професійну допомогу людині, а також іiі сім’і, $\epsilon$ найважливішим завданням соціальної політики. Суспільству потрібні соціальні працівники, здатні ставити і розв'язувати найрізноманітніші і складні завдання професійного характеру, знаходити правильні рішення, актуальні в наш час, i виробляти ефективну технологію своєї трудової діяльності, тобто володіти широким спектром загальнокультурних і професійних компетенцій. Як відзначають дослідники, що займаються вивченням підготовки бакалаврів соціальної роботи, професійне становлення починається 3 перших занять у ЗВО і закінчується протягом перших років професійної діяльності соціального працівника. В даний час професійна підготовка соціальних працівників у ЗВО здійснюється відповідно до Державних освітніх стандартів вищої професійної освіти.

Слід зазначити, що становлення професійної підготовки соціальних працівників пройшло низку етапів:

- перший етап (до 1917 р.). Початок професійної освіти соціальних працівників починається з підготовки християнок-доброходок (сестермилосердя), які надавали допомогу пораненим на полі бою солдатам, а в мирний час - нужденним категоріям населення (сиротам, інвалідам, людям похилого віку). На даному етапі здійснювалося навчання осіб для надання допомоги нужденним і хворим громадянам, організовувалися спеціальні курси при церквах і лікарнях. Так, в 1870-1890-і рр. в громадах були плани навчання сестер, розраховані на п'ять - шість років. У програму навчання входили як медичні предмети, так i релігійні (де прищеплювалися навички надання психологічної допомоги, почуття співпереживання, співчуття), а також здійснювалося навчання технологіям надання соціально-побутової допомоги;

- другий етап (1917-1991рр.). Характеризується розвитком соціальної освіти в рамках системи соціального обслуговування та відсутністю підготовки соціальних працівників як таких (готувалися фахівці, діяльність яких орієнтована на допомогу і підтримку різних верств населення: педагоги, медичні працівники та ін.). Підготовка кадрів для соціальної сфери здійснювалася в рамках короткострокових курсів, організацією яких займалися міністерства та громадські організації (Міжнародний Червоний Хрест і ін.). У 80-і pp. XX ст. можна було здобути середню спеціальну освіту в технікумах соціального забезпечення за спеціальностями: “Обслуговування на дому одиноких непрацездатних громадян”, “Право і організація соціального обслуговування" та iн.;

- третій етап (з 1991 р). Початок цього етапу зумовлено тим, що в кваліфікаційний довідник внесена характеристика "спеціаліст із соціальної роботи”. У тому ж році Держкомітетом СРСР 3 народної освіти була відкрита нова спеціальність для спеціальнопрофесійних і закладів вищої освіти. На даному етапі відбувався бурхливий розвиток професійної освіти в галузі соціальної роботи: розширювалися сфери професійної діяльності соціальних працівників, еволюціонував об'єкт соціальної роботи, послідовно змінювалися стандарти спеціальності і зміст навчання, визначався баланс між теоретичною і практичною підготовкою соціальних працівників;

- четвертий етап (з 2006 р. і до теперішнього часу) пов'язаний з переходом на багаторівневу систему підготовки кадрів, в тому числі і в соціальній сфері. Сучасна система підготовки соціальних працівників в Україні містить досягнення світових і європейських шкіл. Оскільки професійна підготовка майбутніх соціальних працівників є теоретичною основою майбутньої професійної діяльності, то слід зазначити, що у закладах вищої освіти України вона розпочалася трохи більше двадцяти років тому і здійснюється за такими освітньо-кваліфікаційними рівнями: бакалавр спеціальності 6.040200 “Соціальна робота" з наступним переходом до підготовки фахівця 3 повною вищою освітою освітньокваліфікаційного рівня спеціаліст спеціальності 7.040202 “Соціальна робота" і 3 можливим продовженням навчання за другим циклом вищої 


\section{ТЕОРЕТИКО-МЕТОДОЛОГІЧНІ ЗАСАДИЗАБЕЗПЕЧЕННЯ ЯКОСТІ ПІДГОТОВКИСОЦІАЛЬНОГО ПРАЦВНИКА ДОСТВОРЕННЯ ДОСТУПНОГОСЕРЕДОВИЩА В СИСТЕМІ ОБ'ЄДНАНОЇ ТЕРИТОРІАЛЬНОЇ ГРОМАДИ}

освіти - магістр спеціальності 8.13010201 "Соціальна робота".

У зв'язку з наведеними міркуваннями, припускаємо, що основними завданнями в підготовці фахівців з соціальної роботи є:

1) структурна цілісність теоретичної і практичної соціальної роботи;

2) функціональне наповнення змісту освіти, що забезпечує соціальну активність, професійну компетентність, почуття відповідальності й достатній діапазон практичних умінь;

3) взаємозв'язок наукової, методологічної, спеціальної та психолого-педагогічної підготовки фахівців;

4) формування стилю мислення, необхідного для професійного самовдосконалення і розвитку;

5) управління якістю підготовки фахівців.

Нині в Україні функціонують авторські школи соціальної роботи, які розв'язують широке коло теоретичних і практичних питань, пов'язаних із створенням умов для соціального становлення особистості загалом і підготовки соціальних працівників до професійної діяльності зокрема $[8$, $13]$.

На сучасному етапі розвитку суспільства існує потреба у пошуку нових пріоритетів в освіті та підготовці фахівців усіх сфер. Зміна характеру і змісту праці ставить перед суспільством важливі завдання, пов'язані із реформуванням концептуальних, структурних та організаційних засад підготовки спеціалістів, у тому числі і соціальних працівників.

Професійна підготовка як основа готовності до професійної діяльності майбутніх фахівців соціальної роботи здійснюється у більш як 20 3ВО України, зокрема Київському національному університеті імені Тараса Шевченка, Національному університеті “Києво-Могилянська Академія”, Національному педагогічному університеті ім. М. П. Драгоманова, ДВНЗ "Ужгородський національний університет", Тернопільському національну педагогічному університеті імені Володимира Гнатюка, Тернопільському національному економічному університеті, Хмельницькому національному університеті, Чернігівському державному інституті права, соціальних технологій та праці та ін.

Результатом підготовки студентів до фахової соціальної роботи є майбутній соціальний працівник. Насамперед слід конкретизувати сутність поняття “соціальний працівник”. В енциклопедії освіти соціальний працівник - це професійно підготовлений фахівець в галузі соціальної діяльності, котрий відповідає вимогам і характеру виконуваної роботи щодо надання соціальних послуг і схильний за своїми особистісними якостями до їх здійснення.

Отже, соціальний працівник - це професійно підготовлений фахівець, що має необхідну кваліфікацію у сфері соціальної роботи і надає соціальні послуги державних і недержавних організаціях. Діяльність соціального працівника спрямована на надання індивідуальної допомоги людині, сім'ї чи групі осіб, які перебувають у важкій життєвій ситуації, шляхом інформування, діагностування, консультування чи натуральну допомогу, організацію догляду за людьми, що потребують постійної сторонньої допомоги тощо.

На сьогоднішній день основними завданнями підготовки бакалаврів соціальної роботи виступають:

1. Підготовка соціальних працівників 3 урахуванням вимог роботодавців, що висуваються до професійної діяльності.

2. Навчання студентів знань, умінь, дій, що сприяє ефективному і якісному виконанню професійних завдань.

3. Формування у студентів професійної відповідальності, бажання вдосконалювати майстерність професійної діяльності.

4. Формування та вдосконалення студентами компетенцій бакалавра соціальної роботи.

5. Формування у студентів психологічної стійкості особистості студентів та інших важливих професійно-психологічних якостей.

Продовжуючи характеристику теоретичних засад професійної підготовки майбутніх соціальних працівників до створення доступного середовища в системі об'єднаної територіальної громади відзначимо необхідність урахування практичної складової фахового навчання студентів цієї спеціальності.

Практика розглядається як невід'ємна органічна складова освіти в галузі соціальної роботи. Проходження практики майбутніми бакалаврами соціальної роботи сприяє навчанню ïх прийомам і методам роботи 3 різними категоріями населення, що проживають в об'єднаних територіальних громадах, а також дає можливість наблизити студентів безпосередньо до реалій майбутньої роботи. Необхідно відзначити, що в сучасній вітчизняній педагогіці в основі професійної підготовки бакалаврів лежить велика кількість різних науково-педагогічних підходів, які передбачають врахування цілого ряду позицій (ознак, принципів, завдань та ін.), що забезпечують ефективність навчання в освітньому процесі ЗВО.

Педагогічний підхід трактується нами як науково обгрунтований вибір характеру впливу в 


\section{ТЕОРЕТИКО-МЕТОДОЛОГІЧНІ ЗАСАДИЗАБЕЗПЕЧЕННЯ ЯКОСТІ ПІДГОТОВКИСОЦІАЛЬНОГО ПРАЦІВНИКА ДО СТВОРЕННЯ ДОСТУПНОГО СЕРЕДОВИЩА В СИСТЕМІ ОБ'ЄДНАНОЇ ТЕРИТОРІАЛЬНОЇ ГРОМАДИ}

процесі організованого взаємодії педагога i студента, вироблений з метою максимального розвитку особистості як суб'єкта навколишньої дійсності. Педагогічні підходи - деяка проєкція теорії і методики освіти на практику, сфокусована в одній точці, коротка за часом, індивідуалізована в силу найширшого різноманіття персональних особливостей особистості викладача і студента. На основі теоретичного аналізу сучасних досліджень можна виділити підходи до професійної підготовки майбутніх соціальних працівників до створення доступного середовища в системі об'єднаної територіальної громади: особистісноорієнтований, інтегративний, системний, компетентісний.

У професійній підготовці майбутніх бакалаврів соціальної роботи специфіка застосування особистісно орієнтованого підходу полягає в орієнтації студентів на самостійну роботу:

- наукова робота - участь в конференціях, круглих столах, написання грантів;

- волонтерська робота - участь і організація допомоги слабо захищеним верствам населення, інші види самостійної діяльності.

При організації навчання відповідно до даного підходу стимулюється активність кожного студента 3 урахуванням його можливостей $\mathrm{i}$ індивідуальних схильностей (вибір тем курсових і дипломної робіт, вибір бази практики та ін.), Надається вибір групової або тільки власної роботи, оцінка відповіді здійснюється самим студентом, а потім викладачем. Використання індивідуальних завдань (наприклад, при проходженні практики - складання соціального портрета клієнта, соціального паспорта установи) сприяє розвитку самостійності і відповідальності за свою роботу. Особлива увага при навчанні, в рамках особистісно-орієнтованого підходу, приділяється виявленню та розвитку таких унікальних якостей студента (наприклад, вміння керувати своїми емоціями, самоконтроль, комунікабельність, емпатійність та ін.), які будуть необхідні йому в майбутній професійній діяльності. Резюмуючи вищесказане, можна відзначити, що особистісно орієнтований підхід спирається на розуміння того, що особистість - це єдність психічних властивостей, що становлять $\dddot{1}$ індивідуальність.

В умовах реалізації особистісно-орієнтованого підходу в процесі підготовки майбутніх соціальних працівників до створення доступного середовища в системі об'єднаної територіальної громади створюються умови для прояву пізнавальної активності майбутніх бакалаврів соціальної роботи. 3 цією метою доцільно застосовувати:
- різноманітні форми і методи навчання, де не менше $70 \%$ відводиться технологіям інтерактивного навчання;

- засобів створення атмосфери зацікавленості студентами навчальною інформацією;

- різні способи виконання завдання, без боязні помилитися, що, безумовно, важливо, адже у студентів часто виявляється страх виглядати негідно перед однокурсниками;

- змодельовані професійно зорієнтовані ситуації, що дозволяють студентам проявити самостійність і ініціативу.

Інтегративний підхід до підготовки майбутніх соціальних працівників до створення доступного середовища в системі об'єднаної територіальної громади спирається на філософське трактування цілого як нової якості за рахунок іншого способу зв'язку елементів певної структури, а не як суми частин. Процес підготовки майбутніх бакалаврів соціальної роботи в рамках інтеграційного підходу будується на встановленні зв'язків між знаннями. Причому це відбувається не в результаті змін і перебудови навчального плану, а за допомогою дидактичного наповнення дисциплін, створення зв'язків між поняттями, явищами і науками в цілому. При синтезі елементів навчальних дисциплін відбувається їх взаємопроникнення і якісна зміна. При цьому взаємозв'язки можуть бути виражені в різних формах: зв'язків управління і регулювання, зв'язків взаємодії, структурнофункціональних і ієрархічних зв'язків. У цих умовах зміст соціальної освіти визначається зміною змісту і структури професійної діяльності, iii функціями та завданнями $[1,34]$. За таких умов процес професійної підготовки студентів цієї спеціальності $є$ не механічною сумішшю навчальних дисциплін, а їх органічною єдністю, спрямований на досягнення бажаного результату - підвищення рівня професійної компетентності майбутніх бакалаврів соціальної роботи та готовності до створення доступного середовища в системі об'єднаної територіальної громади.

Соціальна робота $є$ живою системою, відповідно, може розглядатися в рамках системного підходу. Людина зі своїми індивідуальними і соціальними особливостями $\epsilon$ головним елементом даної системи. У свою чергу люди, що потрапили у важку життєву ситуацію і потребують сприяння, $\epsilon$ специфічними елементами системи “соціальна робота". Системний підхід в соціальній роботі полягає в тому, що в іiі теорії вивчається виникнення, становлення, функціонування і розвиток даного виду професійної діяльності $[14,134]$. Системним підходом стосовно підготовки майбутніх 


\section{ТЕОРЕТИКО-МЕТОДОЛОГІЧНІ ЗАСАДИЗАБЕЗПЕЧЕННЯ ЯКОСТІ ПІДГОТОВКИСОЦІАЛЬНОГО ПРАЦІВНИКА ДОСТВОРЕННЯ ДОСТУПНОГО СЕРЕДОВИЩА В СИСТЕМІ ОБ'ЄДНАНОЇ ТЕРИТОРІАЛЬНОЇ ГРОМАДИ}

бакалаврів соціальної роботи є така організація професійної підготовки, при якій всі їі компоненти знаходяться у взаємозумовленості, рефлексії та корекції результатів. В рамках даного підходу створюються умови, що забезпечують досягнення ㄲï результативності, формування якостей особистості майбутнього бакалавра, які дозволять йому нестандартно розв'язувати професійні завдання, володіти методикою і інноваційними технологіями професійної діяльності [9]. Щоб ефективно реалізовувати цілі соціальної роботи, бакалавр соціальної роботи повинен володіти великим спектром компетенцій, професійних умінь, навичок, володіти глибокими знаннями в галузі наук про людину. Таким чином, підготовка майбутніх бакалаврів соціальної роботи в освітньому процесі ЗВО є системою організаційних і педагогічних заходів, що забезпечують формування професійної спрямованості, знань, умінь, навичок і компетенції, одержуваних в результаті вивчення навчальних дисциплін і проходження різних видів практик, що сприяє формуванню готовності майбутнього бакалавра соціальної роботи до створення доступного середовища в системі об'єднаної територіальної громади.

Метою реалізації компетентнісного підходу у професійній підготовці майбутніх фахівців цієі спеціальності у ЗВО виступає формування компетентного бакалавра в певній галузі [13]. Специфіка підготовки майбутніх бакалаврів соціальної роботи в рамках компетентнісного підходу полягає в організації ситуацій та стимулюванні дій, які приведуть до формування певної компетенції. Важливим тут $є$ те, що ситуація повинна бути значущою для самого індивіда, мати деяку невизначеність, давати вибір можливостей, відбиваючись в культурному і соціальному досвіді студента. Отже, необхідно моделювати умови і параметри середовища, ситуації професійної діяльності, в яких будуть формуватися і розвиватися конкретні компетенції $[16,112]$.

Продовжуючи, відзначимо, що до теоретикометодологічних засад дослідження відносимо сучасні нормативно-правові документи. Зокрема йдеться про документи, які регламентують професійну діяльність соціальних працівників в системі об'єднаної територіальної громади. У цьому контексті, слушною вважаємо думку Г. Слозанської [15, 267], що у створенні законодавчого підгрунтя для надання соціальних послуг на локальному рівні певні кроки вже зроблено. Зокрема, Верховна Рада ухвалила закони України "Про соціальні послуги", “Про співробітництво територіальних громад”, “Про добровільне об'єднання територіальних громад”, "Концепцію реформування системи соціальних послуг”, “Стратегію подолання бідності”, “Державну стратегію регіонального розвитку на період до 2020 р.”, “Стратегію сталого розвитку “Україна - 2020”, “Національну стратегію у сфері прав людини”, “Стратегію реформування системи надання соціальних послуг до 2022 р.” і плани заходів щодо іiі реалізації, відповідно до яких прийнято 15 державних стандартів соціальних послуг і низку документів, що регулюють процес надання соціальних послуг у системі об'єднаної територіальної громади [14, 133].

Разом 3 тим, дослідниця підкреслює, що вивчення основних підходів до розуміння змісту понять “територіальна громада” та “об”єднана територіальна громада”, їх базових характеристик дозволяє стверджувати, що “об’єднана територіальна громада” є уточненою дефініцією “територіальної громади”, поняттям, яка закріплене на законодавчому рівні нещодавно (2014) у зв'язку реалізацією реформи децентралізації влади. Водночас, поняття “територіальна громада" є більш відоме загалу, змістовніше висвітлене у вітчизняній та зарубіжній науковій літературі та практиці, не суперечить ідеї “об’єднаної територіальної громади” $[13,94]$.

Висновки. Отже, до теоретико-методологічних засад підготовки майбутніх соціальних працівників до створення доступного середовища в системі об'єднаної територіальної громади віднесено: історико-ретроспективні віхи розвитку та фундаменталізації соціальної роботи як практичної професійної діяльності з надання допомоги та підтримки людям; як навчальної дисципліни для підготовки фахівців із соціальної допомоги та підтримки населення; як галузі наукових знань; низку методологічних підходів,до яких віднесено: особистісно-орієнтований, інтегративний, компетентнісний; сучасні нормативно-правові документи, які регламентують професійну діяльність соціальних працівників в системі об’єднаної територіальної громади; фундаментальні дослідження проблем професійної підготовки фахівців соціальної роботи. Перспективи подальших наукових розвідок вбачаємо в обгрунтуванні критеріїв та показників для визначення рівня підготовки соціальнихпрацівників до створення доступного середовища.

\section{ЛІТЕРАТУРА}

1. Боднарук I. Зарубіжний і вітчизняний досвід підготовки майбутніх соціальних працівників до професійної діяльності. Науковий вісник 


\section{ТЕОРЕТИКО-МЕТОДОЛОГІЧНІ ЗАСАДИЗАБЕЗПЕЧЕННЯ ЯКОСТІПІГОТОВКИСОЦАЛЬНОГО ПРАЦІВНИКА ДОСТВОРЕННЯ ДОСТУПНОГОСЕРЕДОВИЩА В СИСТЕМІ ОБ' ЄДНАНОЇ ТЕРИТОРІАЛЬНОЇ ГРОМАДИ}

Ужггородського національного університету. Серія: Педагогіка. Соціальна робота. Ужгород, 2013. № 29. C. 29-33.

2. Боднарук I. I. Формування готовності майбутніх соціальних працівників до професійної діяльності на основі реалізації акмеологічного підходу: дис. . . канд. пед. наук: 13.00.04 / Нац. унт вод. госп-ва і природокористування. Рівне, 2015. $325 \mathrm{c}$.

3. Вачевський М. Сутність компетенцій у навчальному процесі та компетентнісний підхід у професійній освіті. Молодь і ринок. 2012. № 8. C. $25-32$.

4. Жигірь В.І. Наукові підходи до побудови моделі професійної компетентності фахівця. Проблеми трудової і професійної підготовки. Слов'янськ : Слов'янський державний педагогічний університет. 2011. Вип. 16. С. 30-37.

5. Карпенко О. Г. Професійні функції соціального працівника як складова професійної компетентності. Психолого-педагогічні проблеми сільської школи. 2007. Вип. 20. С. 26-33.

6. Костецька М. Розвиток вищої європейської освіти в освітньому вимірі. Молодь і ринок. 2017. № 3. С. 137-142.

7. Про затвердження Національної рамки кваліфікацій: Постанова Кабінету Міністрів України: № 1341 від 23.11.2011 p. URL: http:// zakon4.rada.gov.ua/laws/show/1341-2011-ㅍ (дата звернення: 27.07.2020)

8. Про затвердження плану заходів на 20132016 роки щодо реалізації Стратегії реформування системи надання соціальних послуг: Розпорядження Кабінету Міністрів України № 208-p від 13.03.2013 p. URL: https:// zakon.rada.gov.ua/laws/show/208-2013\%D1\%80\#Text (дата звернення: 27.07.2020)

9. Про схвалення Концепції реформування місцевого самоврядування та територіальної організації влади в Україні : Розпорядження Кабінету Міністрів України № 333-р від 01.04.2014 p. URL: https://zakon.rada.gov.ua/laws/show/3332014-\%D1\%80\#Text (дата звернення: 27.07.2020)

10. Рябова Ю. М. Підготовка майбутніх соціальних працівників до професійної діяльності в багатонаціональному середовищі: дис... канд. пед. наук: 13.00.04. Чорноморський державний університет імені Петра Могили. Миколаїв, 2016. $238 \mathrm{c}$.

11. Семигіна Т. Розвиток власних теорій соціальної роботи: глобальні тенденції. Розвивальний потенціал сучасної соціальної роботи: методологія та технології : матеріали IV Міжнародної науково-практичної конференції (м. Київ 15 - 16 березня 2018 р.) / за ред.
Ю.М. Швалба. Київ : КНУ імені Тараса Шевченка. 2018. С. 90-194.

12. Слозанська Г. І. Діяльність інтегрованих соціальних служб в умовах ОТГ. Scientific Papers: Social Work and Education. CSI\&D, 2016. Vol. 3 (1). P. 115-122.

13. Слозанська Г. І. Організація громади як метод соціальної роботи в громаді. Вісник Черкаського університету. Серія : Педагогічні науки. Черкаси, 2016. № 16. С. 130-136.

14. Слозанська Г. І. Упровадження посади фахівця із надання соціальних послуг населенню в умовах об'єднаної територіальної громади: труднощі, що виникають. Вісник Луганського національного педагогічного університету імені Тараса Шевченка. Старобільськ, 2017. Ч.1. №1 (306). C. 264-276.

15. Doel M., Marsh P. Task-centred social work. Routledge, 2017. 160 p.

16. Donovan J., Rose D., \& Connolly M. A Crisis of Identity: Social Work Theorising at a Time of Change. The British Journal of Social Work, 2017. $180 \mathrm{p}$.

17. Horishna N., Slozanska H. Dual Degree Programs In Social Work: is it Possible in Ukraine? Economics and Sociology. 2017. Vol. 10(2). P.165178.

\section{REFERENCES}

1. Bodnaruk, I. (2013). Zarubizhnyi i vitchyznianyi dosvid pidhotovky maibutnikh sotsialnykh pratsivnykiv do profesiinoi diialnosti [Foreign and domestic experience in training future social workers for professional activities]. Scientific Bulletin of Uzhhorod National University. Series: Pedagogy. Social work, No. 29, pp. 29-33. [in Ukrainian].

2. Bodnaruk, I. (2015). Formuvannia hotovnosti maibutnikh sotsialnykh pratsivnykiv do profesiinoi diialnosti na osnovi realizatsii akmeolohichnoho pidkhodu [Formation of readiness of future social workers for professional activity on the basis of realization of the acmeological approach]. Candidate's thesis. Rivne, 325 p. [in Ukrainian].

3. Vachevskyi, M. (2012). Sutnist kompetentsii u navchalnomu protsesi ta kompetentnisnyi pidkhid $u$ profesiinii osviti [The essence of competencies in the educational process and the competence approach in vocational education]. Youth and the market, No. 8, pp. 25-32. [in Ukrainian].

4. Zhyhir, V.I. (2011). Naukovi pidkhody do pobudovy modeli profesiinoi kompetentnosti fakhivtsia [Scientific approaches to building a model of professional competence of a specialist]. Problems of labor and professional training, No. 16, pp. 3037. [in Ukrainian]. 


\section{ТЕОРЕТИКО-МЕТОДОЛОГІЧНІ ЗАСАДИ ЗАБЕЗПЕЧЕННЯ ЯКОСТІ ПІДГОТОВКИСОЦАЛЬНОГО ПРАЦІВНИКА ДОСТВОРЕННЯ ДОСТУПНОГОСЕРЕДОВИЩА В СИСТЕМІ ОБ'ЄДНАНОЇ ТЕРИТОРІАЛЬНОӤ ГРОМАДИ}

5. Karpenko, O. G. (2007). Profesiini funktsii sotsialnoho pratsivnyka yak skladova profesiinoi kompetentnosti [Professional functions of a social worker as a component of professional competence]. Psychological and pedagogical problems of rural school, No. 20, pp. 26-33. [in Ukrainian].

6. Kostecka, M. (2017). Rozvytok vyshchoi yevropeiskoi osvity $\mathrm{v}$ osvitnomu vymiri. [Development of European higher education in the educational dimension]. Youth and the market, No. (3), pp. 137-142. [in Ukrainian].

7. Pro zatverdzhennia Natsionalnoi ramky kvalifikatsii: Postanova Kabinetu Ministriv Ukrainy № 1341 vid 23.11.2011 r. [Resolution of the Cabinet of Ministers of Ukraine "On approval of the National Qualifications Framework" from 23.11.2011 NO. 1341]. Available at : http://zakon4.rada.gov.ua/laws/ show/1341-2011-p. (accessed 27 July 2020) [in Ukrainian].

8. Pro zatverdzhennia planu zakhodiv na 20132016 roky shchodo realizatsii Stratehii reformuvannia systemy nadannia sotsialnykh posluh: Rozporiadzhennia Kabinetu Ministriv Ukrainy № 208-r vid 13.03.2013 r. [On approval of the Action Plan for 2013-2016 on the implementation of the Strategy for reforming the system of social services: Order KMU from 13.03.2013 No. 208-r]. Available at : http: // zakon2. work. gov. ua / laws / show / 208-2013-\% D1, 80 (accessed 27 July, 2020 2019) [in Ukrainian].

9. Pro skhvalennia Kontseptsii reformuvannia mistsevoho samovriaduvannia ta terytorialnoi orhanizatsii vlady v Ukraini : Rozporiadzhennia Kabinetu Ministriv Ukrainy № 333-r vid 01.04.2014 r. [On approval of the Concept of reforming local selfgovernment and territorial organization of power in Ukraine: Order KMU]. Available at : http:// zakon3.rada.gov.ua/laws/show/333-2014-\%D1\%80 (accessed 27 July, 2020 2019) [in Ukrainian].

10. Ryabova, Yu. M. (2016). Pidhotovka maibutnikh sotsialnykh pratsivnykiv do profesiinoi diialnosti v bahatonatsionalnomu seredovyshchi [Preparation of future social workers for professional activity in a multinational environment]. Candidate's thesis. Mykolaiv, 238 p. [in Ukrainian].

11. Semigina, T. (2018). Rozvytok vlasnykh teorii sotsialnoi roboty: hlobalni tendentsii [Development of own theories of social work: global trends]. Rozvyvalnyi potentsial suchasnoi sotsialnoi roboty: metodolohiia ta tekhnolohii: Proceedings of the of the IV International scientific-practical conference (March 15 - 16, 2018, Kyiv) / Ed. Yu.M. Schwalba. Kyiv: Taras Shevchenko National University, pp. 90-194. [in Ukrainian].

12. Slozanskaya, G. I. (2016). Diialnist intehrovanykh sotsialnykh sluzhb v umovakh OTH [Activities of integrated social services in terms of OTG]. Scientific Papers: Social Work and Education. CSI \& D, No. 3 (1), pp. 115-122. [in Ukrainian].

13. Slozanska, H. I. Orhanizatsiia hromady yak metod sotsialnoi roboty $\mathrm{v}$ hromadi [Community organization as a method of social work in the community]. Bulletin of Cherkasy University. Series: Pedagogical sciences. Cherkasy, 2016. No. 16, pp. 130-136. [in Ukrainian].

14. Slozanska, H. I. (2017). Uprovadzhennia posady fakhivtsia iz nadannia sotsialnykh posluh naselenniu $\mathrm{v}$ umovakh obiednanoi terytorialnoi hromady: trudnoshchi, shcho vynykaiut [Introduction of the position of a specialist in providing social services to the population in a united territorial community: difficulties that arise]. Bulletin of Luhansk Taras Shevchenko National Pedagogical University, No. 1 (306), pp. 264-276. [in Ukrainian].

15. Doel, M. \& Marsh, P. (2017). Task-centred social work. Routledge, 160 p. [in English].

16. Donovan, J., Rose, D., \& Connolly, M. (2017). A Crisis of Identity: Social Work Theorising at a Time of Change. The British Journal of Social Work, 180 p. [in English].

17. Horishna, N. \& Slozanska, H. (2017). Dual Degree Programs In Social Work: is it Possible in Ukraine? Economics and Sociology. Vol. 10(2), pp. 165-178. [in English].

Стаття надійшла до редакції 27.05.2020

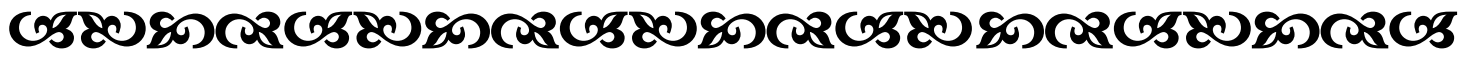 $\% * \% * \% * \% * \%$}

“Сила харақтеру, незалежно від його змісту, - сқарб, яқий нічим не замінити. Вона почерпується єдино з природних джерел душі, $і$ виховання повинно над усе берегти ию силу, якоснову всякої людської гідності ".

Костянтин УУиинський уқраїнський педагог

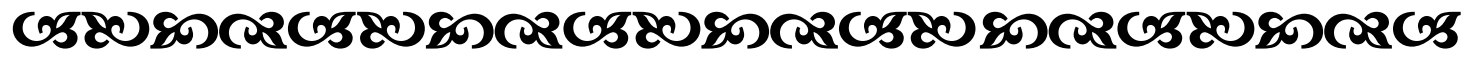

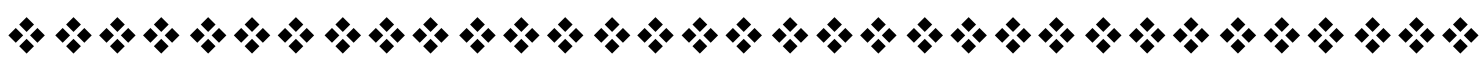

